\title{
Prognostic Factors Affecting Survival In Patients With Operable Non-Small Cell Lung Cancer: Single Center Experience and Review of The Literature
}

\author{
Opere Küçük Hücreli Dışı Akciğer Kanserli Hastalarda Sağkalım Üzerine Etkili Faktörler: Tek Merkez Deneyimi \\ ve Literatürün Gözden Geçirilmesi
}

\author{
Arife Ulas ${ }^{1}$, Fatma Paksoy Turkoz ${ }^{1}$, Ayşe Gok Durnalı ${ }^{1}$, Erkan Arpacı ${ }^{1}$, Ahmet Bilici ${ }^{2}$, Saadet Tokluoglu ${ }^{1}$, Necati Alkıs ${ }^{1}$
}

${ }^{1}$ Ankara Oncology Teaching and Research Hospital, Department of Medical Oncology, Ankara, Turkey

${ }^{2}$ Sisli Etfal Teaching and Research Hospital, Department of Medical Oncology, Istanbul, Turkey

\section{ABSTRACT}

Objective: Although early-stage lung cancer patients are curable, the prognosis is limited and the 5-year survival rates range from 40 to 65 percent. In this study, clinicopathologic features, treatment responses and prognostic factors of non-small cell lung cancer patients treated with surgery were investigated.

Methods: Seven-hundred-thirty-eight non-small cell lung cancer patients diagnosed and followed up between the years of 1999 and 2009 were evaluated retrospectively. Eighty patients who underwent surgery were included in the study.

Results: There were 71 male and 9 female patients with the median age of 55 years (range, 39 to 71). Forty-six-point-three percent of the patients had squmous cell cancer and $35 \%$ had adenocarcinoma. Thirty-one patients had stage I, 30 had stage II and 19 had stage IIIA disease. Forty-six percent of the patients had adjuvant radiotherapy and $50.7 \%$ had adjuvant chemotherapy. The median follow-up time after diagnosis was 34.2 months (range, 12 -132), the 5-year overall survival and the 5-year disease free survival rates were $45.5 \%$ and $32.8 \%$, respectively. Performance status $(p=0.024)$, tumor size $(p=0.015)$, lymph node involvement $(p=0.015)$ and anemia $(p=0.001)$ were the prognostic factors associated with the overall survival. Stage $(p=0.005)$, anemia $(p=0.007)$ and adenocarcinoma subtype $(p<0.001)$ significantly affected the disease free survival.

Conclusion: The performance status, stage, nodal involvement, presence of anemia are the prognostic factors affecting the survival in patients with nonsmall cell lung cancer.

Key Words: Non-small cell lung cancer, early stage, operable, survival, prognostic factors

Received: 12.29 .2013

Accepted: 02.112014

\section{ÖZET}

Giriş: Erken evre akciğer kanserli hastalar kürabl olabilmesine rağmen, prognoz sınırlı olup, 5-yıllık sağkalım oranları \% 40-65 arasında değişmektedir. Bu çalışmada, cerrahi uygulanmış küçük hücreli dışı akciğer kanserli hastalarda klinikopatolojik özellikler, tedavi yanıtları ve prognostik faktörler araştırılmıştır.

Yöntemler: 1999 - 2009 yılları arasında takip edilen 738 küçük hücreli dışı akciğer kanseri tanılı hastanın verileri retrospektif olarak incelenerek, cerrahi uygulanmış 80 hasta çalışmaya dahil edildi.

Bulgular: Hastaların 71'i erkek ve 9'u kadın olup, ortanca yaş 55 yıl (39-71) idi. Yüzde 46.3'ü yassı hücreli ve \% 35'i adenokarsinomaydı. Hastaların 31'i Evre I, 30'u evre II ve $19^{\prime}$ u evre IIIA'ydı. Adjuvan radyoterapi hastaların \% 46 'sına, kemoterapi ise \% 50.7'sine uygulanmıştı. Ortanca takip süresi 34.2 ay (12-132), 5-yıllık genel sağkalım \% 45.5, 5-yıllık hastalıksız sağkalım oranı ise \%32.8 bulundu. Performans durumu ( $p=0.024)$, tümör boyutu $(p=0.015)$, nodal tutulum $(p=0.015)$ ve anemi varlığı $(p=0.001)$ genel sağkalımı etkileyen prognostik faktörler iken, evre $(p=0.005)$, anemi varlığı $(p=0.007)$ ve histopatolojik tipin adenokanser olmasının $(p<0.001)$ hastalıksız sağkalım üzerine etkili olduğu görüldü.

Sonuç: Opere edilmiş, küçük hücreli dışı akciğer kanserli olgularda performans durumu, evre, anemi varlığı ve nodal tutulum sağkalımı etkileyen faktörlerdir.

Anahtar Sözcükler: Küçük hücreli dışı akciğer kanseri, erken evre, opere edilebilir, sağkalım, prognostik faktör

Geliş Tarihi: 29.12 .2013

Kabul Tarihi: 11.022014

Address for Correspondence / Yazışma Adresi: Arife Ulas MD, Ankara Oncology Teaching and Research Hospital, Department of Medical Oncology, 12. Street, 06310 Yenimahalle, Ankara, Turkey Phone: 905052519623 E-mail: drarifeulas@hotmail.com

CTelif Hakkı 2014 Gazi Üniversitesi Tıp Fakültesi - Makale metnine http://medicaljournal.gazi.edu.tr/ web adresinden ulaşılabilir.

(C) Copyright 2014 by Gazi University Medical Faculty - Available on-line at web site http://medicaljournal.gazi.edu.tr/

doi: http://dx.doi.org/10.12996/gmj.2014.02 


\section{INTRODUCTION}

Lung cancer commonly occurs all over the world and is the leading cause of the cancer associated deaths (1). Although surgery is the standard treatment method for non-small cell lung cancer (NSCLC), which provides a long-term cure, 5 year survival rates at stages I, II and IIIA are 57-67\%, 38$55 \%$ and $23 \%$, respectively $(2,3)$. About half of the patients die within five years of the diagnosis. Most of the deaths are associated with cancer recurrence, which usually arises in extrathoracic distant regions and supports micrometastatic disease during surgery (4). In patients with operable NSCLC, the aim of an efficacious systemic treatment is to decrease the risk of recurrence and to improve survival by eliminating micrometastatic disease.

Many prognostic factors have been evaluated in patients with operable NSCLC and negative prognostic factors were established to be stage, poor performance status (PS), loss of weight and the presence of symptoms. In various studies, it was determined that preoperative hemoglobin level, age, sex and histopathological type were also probable prognostic factors $(4,5,6)$. In two important reviews by Grazione and Strauus, authors pointed out the few numbers of patients in the studies, their heterogenity and the importance of subgroup analysis $(7,8)$. In patients with NSCLC, improvements were brought about in survival by means of adjuvant cytotoxic treatments and novel targeted treatments and epidermal growth factor receptor inhibitors, yet, factors influential on recurrence rates after surgery and the development of distant metastasis still remain to be elucidated.

The aim of the present study was to investigate the factors associated with disease-free survival (DFS) and overall survival (OS) in early stage NSCLC patients who have undergone surgery in a single center and were followed up over a ten-year period.

\section{METHODS}

In the present study, the files of 738 patients who were followed up in Dr. Abdurrahman Yurtarslan Ankara Oncology Training and Investigation hospital, Medical Oncology clinic between June 1999- April 2009 with the diagnosis NSCLC were retrospectively investigated upon aproval of hospital ethics committee. Eighty patients with NSCLC who were diagnosed with histopathologically or cytologically and underwent surgical resection were included in the present study.

Clinical characteristics of the patients (age, sex, ECOG PS, symptoms at the time of diagnosis, weight loss, smoking history) histological type, stage and treatment modalities were recorded. The diagnosis of patients with NSCLC was mostly made with either bronchoscopic biopsy or transthoracic fine needle aspiration biopsy or mediastinoscopic biopsy. Forty patients were diagnosed with bronchoscopic biopsy, 38 with transthoracic biopsy and 2 with mediastinoscopic biopsy. Staging was made according to WHO classification (9,10). Histological analyis was also made with WHO classification (11). Performance status evaluation was made according to ECOG PS (Eastern Cooperative Oncology Group Performance Score) (12). Prior to operation, labaratory parameters, hemoglobin, leukocyte, thrombocyte levels, serum albumin level, lactat dehidrogenase level (LDH) and adjuvant radiotherapy (RT) and adjuvant chemotherapy (CT) regimes were recorded.

The evaluation of the response to treatment was determined according to World Health Organization (WHO) criteria (3). Complete response was defined as lesion being no longer detected, partial response (PR) as the regression of lesion by $\geq \% 50$ or the enlargement of lesion by $<\% 25$, and progressive disease (PD) as the enlargement of lesion by $>\% 25$ or the development of new lesions.

The overall survival was defined as the duration of time from the date of diagnosis to the date of death or the date of death learned from relatives by phone and in cases of those who could not be reached to the last visit to our clinic (months). The local-regional recurrence was considered as the detection of cancer in supraclavicular lymph nodes, mediastinal lymph nodes and ipsilateral lung, and the distant metastasis as the detection of cancer in contralateral lung, brain, liver, bone, adrenal gland and other organs. The disease-free survival was defined as the time from the date when the patient underwent operation to the date when a distant metastasis developed.

\section{Statistical Analysis}

Descriptive statistics were expressed as mean \pm standard deviation or median (minimum-maximum) for continuous variables and as the number of cases and percentage (\%) for categorical variables. Whether the probable categorical risk factors have any statiscally significant effect on DFS and OS was evaluated by uni- and multi-variate analysis and a survival analysis was carried out through Kaplan Meier survival analysis and Log-Rank test. Crude survival 1-, 2- and 5-year survival rates, expected survival and their 95\% confidence intervals were calculated. Appropriate statistical analysis was carried out and a two-sided level of $<0.05$ was considered as statistically significant. All data were entered and analyzed by using Statistical Package for Social Sciences version 11.5 (SPSS, Inc., Chicago, IL, USA).

\section{RESULTS}

\section{Demographic and clinicopathological characteristics}

Out of eighty patients, 71 (89\%) were male and $9(11 \%)$ were female. The median age was 55 years (range, 39-71) and the median duration follow-up was 34.2 months (range, 12-13). More than $90 \%$ of the patients were less than 65 years old and $66 \%$ were in ECOG PS 1 . Histopathologically, $46.3 \%$ were squamous cell and $35 \%$ were adenocarcinoma. Smoking history was present in $84.3 \%$ of the cases. Tumor was localized in the right lung in the $55 \%$ and the most frequent localization was the right upper lobe with a $36.4 \%$. The distribution of the stage of disease was as follows: The $7.5 \%$ were in stage $I A$, the $31.2 \%$ in IB, the $1.2 \%$ in IIA, the $36.2 \%$ in IIB and the $23.7 \%$ in IIIA. Patient and tumor characateristics are shown in Table 1.

\begin{tabular}{|c|c|}
\hline Variables & Number of patients (\%) \\
\hline Age (year) median & $55(39-71)$ \\
\hline$\leq 65$ & $72(90)$ \\
\hline$>65$ & $8(10)$ \\
\hline \multicolumn{2}{|l|}{ Sex } \\
\hline Male & $71(89)$ \\
\hline Female & $9(11)$ \\
\hline \multicolumn{2}{|l|}{ Smoking } \\
\hline Smoker & $65(82)$ \\
\hline Non-Smoker & $15(18)$ \\
\hline \multicolumn{2}{|l|}{ ECOG PS } \\
\hline 0 & $6(7.5)$ \\
\hline 1 & $53(66.3)$ \\
\hline 2 & $21(26.3)$ \\
\hline \multicolumn{2}{|l|}{ Comorbid disease } \\
\hline Present & $31(38.8)$ \\
\hline Absent & $49(61.3)$ \\
\hline \multicolumn{2}{|l|}{ Histology } \\
\hline NSCLC -NOS & $3(3.8)$ \\
\hline SCC & $37(46.3)$ \\
\hline$A C$ & $28(35)$ \\
\hline LCC & $6(7.5)$ \\
\hline Others* & $6(7.5)$ \\
\hline \multicolumn{2}{|l|}{ T stage } \\
\hline $\mathrm{T} 1$ & $5(6.3)$ \\
\hline $\mathrm{T} 2$ & $48(60.8)$ \\
\hline T3 & $27(33.8)$ \\
\hline \multicolumn{2}{|l|}{$\mathbf{N}$ stage } \\
\hline NO & $32(40.5)$ \\
\hline N1 & $25(31.3)$ \\
\hline N2 & $22(27.9)$ \\
\hline \multicolumn{2}{|l|}{ Stage } \\
\hline IA & $6(7.5)$ \\
\hline IB & $25(31.25)$ \\
\hline IIA & $1(1.2)$ \\
\hline IIB & $29(36.2)$ \\
\hline IIIA & $19(23.7)$ \\
\hline \multicolumn{2}{|l|}{ Adjuvant RT } \\
\hline Present & $37(46.1)$ \\
\hline Absent & $43(53.9)$ \\
\hline \multicolumn{2}{|l|}{ Adjuvant CT } \\
\hline Present & $38(47.5)$ \\
\hline Absent & $42(52.5)$ \\
\hline \multicolumn{2}{|l|}{ Surgery } \\
\hline Pneumectomy & $16(20)$ \\
\hline Lobectomy & $61(76.2)$ \\
\hline Segmentectomy & $3(3.8)$ \\
\hline
\end{tabular}

NSCLC: non small cell lung cancer, NOS: not otherwise specified, SCC: squamous cell carcinoma, AC: adenocarcinoma, LCC: large cell carcinoma. *The other rarer subtypes included anaplastic, sarcomatoid carcinoma, angiosarcoma and mucoepidermoid carcinoma.

The most common presenting symptoms were dyspnea and cough $(60 \%$ and $55.8 \%$, respectively). The most common comorbid diseases were 
chronic obstructive lung disease $(37.9 \%)$, hypertension $(27.1 \%)$, coronary artery disease $(24.1 \%)$ and diabetes mellitus (20.7\%).

Fifty percent of the patients were diagnosed with fiberoptic bronchoscopy and the $42 \%$ with transthoracic needle biopsy and the $8 \%$ with mediastinoscopic biopsy. At the time of diagnosis, anemia was found in the $44.1 \%$, leukocytosis in the $31 \%$, thrombocytosis in the $17.6 \%$, high LDL in the $3.6 \%$, high alkalene phopshatase levels in the $10.7 \%$ and low albumin levels in the $10.6 \%$.

When surgical methods were compared, it was determined that 61 patients underwent lobectomy, 16 pneumenectomy and 3 segmentectomy. In addition, $46 \%$ of the patients received adjuvant RT and the $47.5 \%$ adjuvant chemotherapy (CT). In adjuvant chemotherapy, the most commonly used combination regime was cisplatin-vinorelbin administered in a median of 4 cycles (19 patients). Eight patients received cisplatin-etoposid, 4 patients platin-gemcitabin, 3 patients cisplatin-docetaxel, 1 patient cisplatin-paclitaxel and 1 patient 5-fluorauracil-doxorubicin-cisplatin combination CT.

\section{Survival analysis}

In a mean of 34.2 month(range,12-132)-follow-up period, recurrence was detected in 42 patients (52.5\%) and in 35 of these cases(43\%) the distant metastasis was detected. The most frequent location of distant metastasis was brain. Out of 48 surviving patients, 26 had complete remission, 10 a stable disease and 12 a progressive disease. Mean duration of OS was found to be 53 months $(95 \% \mathrm{Cl} ; 15.8-90.2)$, and at the end of the first year, the survival rate was $86.8 \%$, at the end of the second year, $74.3 \%$ and at the end of the fifth year, $45.5 \%$ (Figure 1A). The mean DFS was 31 months $(95 \% \mathrm{Cl}$; 14.9- 47.08), and the 1-, 2- and 5-year disease free survival rates were $74.1 \%, 57 \%$ and $32.8 \%$, respectively (Figure $1 B$ ).

Mean OS in stage I, II and IIIA disease was 76, 82 and 47 months, respectively $(p=0.015)$; and median DFS was found to be 39,34 and 23 months, respectively $(p=0.005)$ (Figure $2 A$ and $2 B)$. Nodal involvement was established to be influential on OS ( $p=0.015)$. In N0, N1 and N2 disease, the 5 -year OS rates were found to be $55.1 \%, 41 \%$ and $31.9 \%$, respectively (Figure 3).
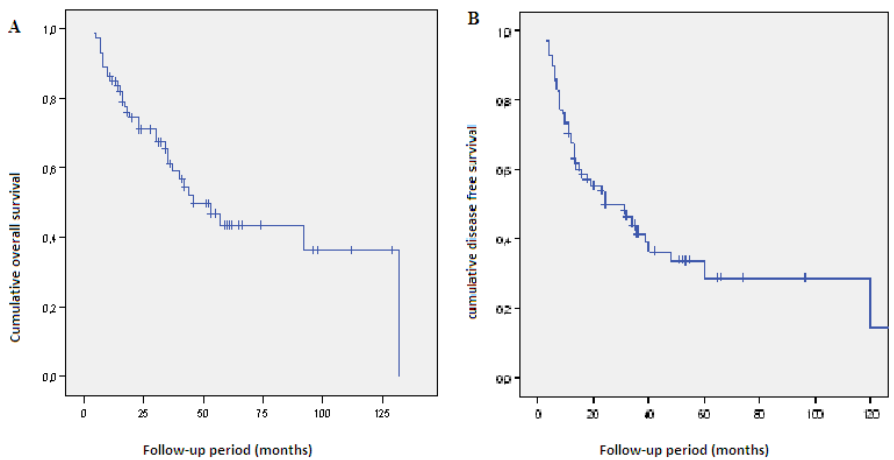

(A) 1-year OS, 86.8\%; 2-year OS, 74.3\%; 5-year OS, $45.5 \%$

(B) 1-year DFS, 74.1\%; 2-year DFS, 57\%; 5-year DFS, 32.8\%

Figure 1: Overall survival(A) and Disease Free Survival(B) for patients who underwent surgerv

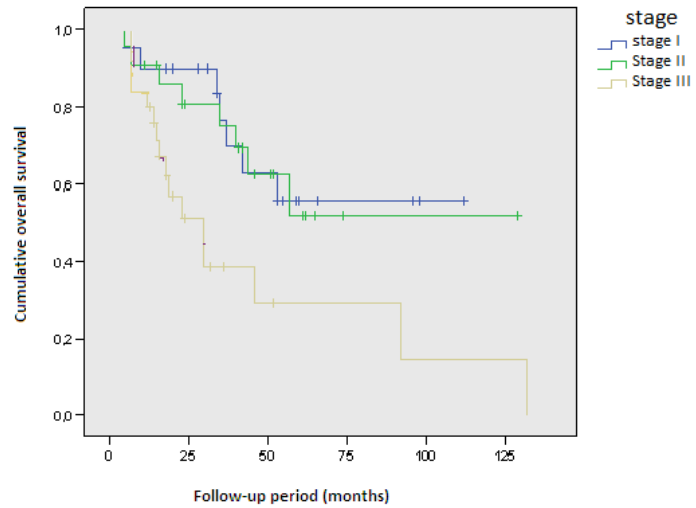

Overall survival according to stages (in stage I 76 months $(\% 95 \mathrm{Cl}$; 56.9-96.8), stage II 82 months (\% $95 \mathrm{GCl} 58.4-07.2$ ), stage IIIA 47 months (\% $95 \mathrm{GA} ; 24.9-69.7)$; $p=0.015$ ).

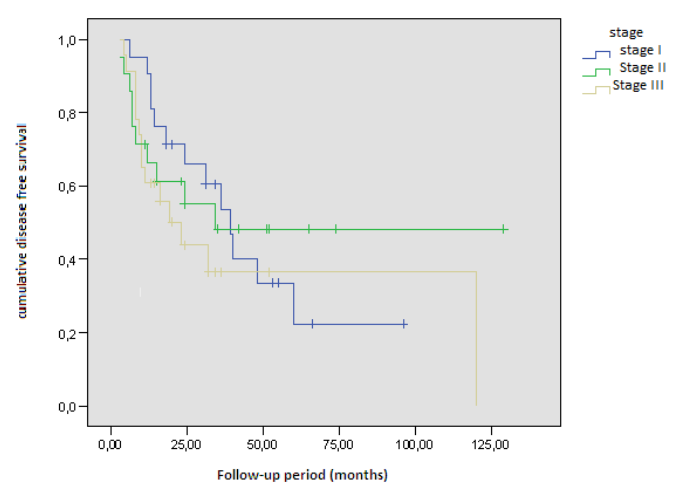

DFS according to stages ( in stage I 39 months (\% 95 GA 28.5-49.4 ), stage II 34months (\% 95 GA 26.5-46.4), stage IIIA 23 months(\% 95 GA 10.835.947); $p=0.015)$.

Figure 2B. Disease Free Survival curves according to the clinical stage
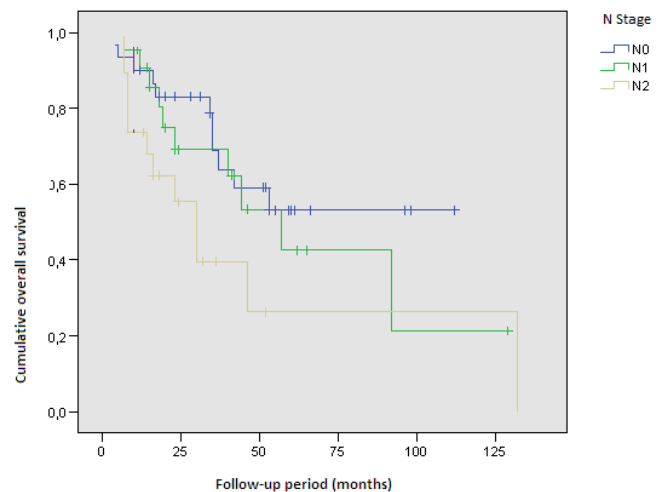

Overall survival according to $\mathrm{N}$ stage (in stage N0; 75.4 months $(\% 95 \mathrm{Cl}$; 58.0-92.9) $)^{\mathrm{a}}$, N1 57 months (\% $95 \mathrm{Cl}$; 32.9-81.1), N2 30 months $(\% 95 \mathrm{Cl}$; 11.7-48.3); $p=0.015)$

Figure 3. Overall survival according to $\mathrm{N}$ stage

In patients with Performans Status of ECOG 0, 1 and 2, the median DFS duration was found to be 60,39 and 19 months, respectively $(p=0.046)$. In patients who had ECOG PS 0 and 1, the survival was found to be better $(p=0.024)$. In patients with adenocarcinoma, DFS duration was shorter as compared with patients with squamous cell carcinoma ( 24 months vs. 60 months) ( $p<0.001)$. In a univariate analysis, it was found that the presence of anemia had an adverse impact on the duration of both DFS and OS (respectively, $\mathrm{p}=0.007$ and $\mathrm{p}=0.01$ ). In non-smokers, the mean survival expectation was found to be longer, although the difference was marginally significant $(p=0,087)$. In non-smokers, the 2- and 5-year OS rates were $88.9 \%$ and $66.7 \%$, respectively while in smokers it was $56.4 \%$ and $34.2 \%$, respectively. In patients at the age of 65 and below, the mean OS duration was found to be longer than those of the patients over the age of 65 (53 months vs. 30 months). However, this difference was not statistically significant $(p=0,491)$. In addition, the mean duration of OS was found to be longer in male patients, even though the difference was not statistically significant ( 75 months vs. 53 months; $p=0,335$ ). It was also observed that an albumin level of $3 \mathrm{gr} / \mathrm{dL}$ or below, high LDL levels and leukocytosis had an negative impact on both OS and DFS, even though it did not reach the statistical significance.

It was also determined that adjuvant $\mathrm{RT}$ and $\mathrm{CT}$ received by patients had a favorable effect on DFS, but the difference did not reach the statistical significance. No effect of adjuvant RT and CT on OS was observed. However, in a subgroup analysis, adjuvant RT was found to have a positive effect on OS in stage IIB disease $(p=0.069)$ with a marginal significance. Besides, adjuvant $\mathrm{CT}$ was found to exert a statistically significant positive effect on OS in stage IIB (116 months vs. 40 months; $p=0.002$ ). The 2 - and 5 -year OS rates in those receiving adjuvant $\mathrm{CT}$ were $82.5 \%$ and $48.3 \%$, respectively, while in those receiving adjuvant $\mathrm{RT}$ the rates were $80.1 \%$ and $68.9 \%$, respectively.

Figure 2A. Overall survival curves according to the clinical stage 
Table 2. Univariate analysis results for Overall survival and Dissease free survival

\begin{tabular}{|c|c|c|c|c|c|c|}
\hline \multirow[b]{2}{*}{ Variables } & \multicolumn{3}{|c|}{ Dissease free survival } & \multicolumn{3}{|c|}{ Overall survival } \\
\hline & Median (\%95 Cl) & HR & $\begin{array}{l}P_{\text {log- }} \\
\text { rank }\end{array}$ & Median (\%95 Cl) & HR & $P_{\text {log-rank }}$ \\
\hline Age & & 0.61 & 0.434 & & 0.47 & 0.491 \\
\hline$\leq 65$ & $78.0(33.0-123.0)^{a}$ & & & $53.0(15.1-90.9)$ & & \\
\hline$>65$ & $34.0(19.2-48.8)$ & & & $30.0(2.1-57.9)$ & & \\
\hline Sex & & 0.11 & 0.745 & & 0.93 & 0.335 \\
\hline Male & $36.0(17.8-54.2)$ & & & $53.0(33.3-72.7)$ & & \\
\hline Female & $34.0(12-74.1)$ & & & $\begin{array}{l}75.6 \\
101.8)^{\mathrm{a}}\end{array}$ & & \\
\hline ECOG PS & & 4.68 & 0.046 & & 7.49 & 0.024 \\
\hline 0 & $60.0(17-158.0)$ & & & $\begin{array}{l}91.7 \\
147.6)^{\mathrm{a}}\end{array}$ & & \\
\hline 1 & $39.0(31.7-46.3)$ & & & $92.0(25.8-158.2)$ & & \\
\hline 2 & $19.0(3.0-35.0)$ & & & $23.0(5.7-40.3)$ & & \\
\hline Pathology & & 4.94 & 0.294 & & 4.85 & 0.303 \\
\hline NSCLC-NOS & $61.0(43.0-79.0)^{\mathrm{a}}$ & & & - & & \\
\hline $\mathrm{SCC}$ & $60.0(26.0-119.0)$ & & & $37.0(20.1-53.9)$ & & \\
\hline$A C$ & $24.0(11.0-37.0)$ & & & $46.0(36.8-55.2)$ & & \\
\hline LCC & $27.7(16.4-39.1)^{\mathrm{a}}$ & & & $35.0(7.4-62.6)$ & & \\
\hline other & $40.0(38.4-41.6)$ & & & $47.7(53.9-61.4)^{\mathrm{a}}$ & & \\
\hline Smoking history & & 3.59 & 0.166 & & 4.89 & 0.087 \\
\hline Non-Smoker & $34.0(24-75.3)$ & & & $\begin{array}{l}75.6 \\
101.8)^{a}\end{array}$ & & \\
\hline Smoker & $19.0(5.4-32.6)$ & & & $37.0(26.8-51.2)$ & & \\
\hline Weight loss & & 0.64 & 0.425 & & 1.38 & 0.240 \\
\hline Absent & $32.0(8.4-55.6)$ & & & $46.0(25.4-66.6)$ & & \\
\hline Present & $34.0(0.0-81.2)$ & & & $52.5(39.8-65.2)^{\mathrm{a}}$ & & \\
\hline Anemia & & 3.49 & 0.007 & & 0.06 & 0.01 \\
\hline Absent & $72.1(50.3-84.0)^{\mathrm{a}}$ & & & $92.0(20.2-163.2)$ & & \\
\hline Present & $19.0(11.4-41.1)$ & & & $16.0(3.1-28.80)$ & & \\
\hline White cell & & 0.46 & 0.498 & & 0.00 & 0.959 \\
\hline$<10.000$ & $32.0(18.8-45.2)$ & & & $46.0(22.4-105,2)$ & & \\
\hline$\geq 10.000$ & $43.3(30.1-56.5)^{\mathrm{a}}$ & & & $47.0(34.7-59.1)^{a}$ & & \\
\hline Platelet & & 1.78 & 0.182 & & 1.35 & 0.245 \\
\hline Normal & $34.0(23.7-44.2)$ & & & $92.0(10.7-173.2)$ & & \\
\hline Thrombocytosis & $19.0(5.1-32.9)$ & & & $30.0(11.6-60.3)$ & & \\
\hline $\mathrm{LDH}(\mathrm{U} / \mathrm{L})$ & & 0.43 & 0.510 & & 1.64 & 0.201 \\
\hline$<450$ & $31.0(18.5-43.5)$ & & & $44.0(32.4-55.6)$ & & \\
\hline$\geq 450$ & $11.5(12-23.3)$ & & & $12.5(2.1-22.9)^{\mathrm{a}}$ & & \\
\hline Albumin & & 0.68 & 0.409 & & 0.22 & 0.635 \\
\hline$\leq 3 \mathrm{~g} / \mathrm{dl}$ & $15.0(3.5-26.5)$ & & & $37.5(17.6-57.3)^{\mathrm{a}}$ & & \\
\hline$>3 \mathrm{~g} / \mathrm{dl}$ & $36.0(23.1-48.9)$ & & & $57.0(9.3-104.7)$ & & \\
\hline T stage & & 0.33 & 0.396 & & 4.95 & 0.175 \\
\hline $\mathrm{T} 1$ & $39.0(15.6-62.4)$ & & & $53.0(22.6-83.4)$ & & \\
\hline $\mathrm{T} 2$ & $32.0(18.6-45.3)$ & & & $57.0(28.5-85.5)$ & & \\
\hline T3 & $16.0(13.2-18.7)$ & & & $61.3(35.0-87.6)^{\mathrm{a}}$ & & \\
\hline N stage & & 0.53 & 0.166 & & 3.50 & 0.015 \\
\hline NO & $39.0(12.8-59.2)$ & & & $75.4(58.0-92.9)^{\mathrm{a}}$ & & \\
\hline N1 & $24.0(2.6-43.4)$ & & & $57.0(32.9-81.1)$ & & \\
\hline N2 & $23.0(11.6-46.4)$ & & & $30.0(11.7-48.3)$ & & \\
\hline TNM stage & & & 0.005 & & & 0.015 \\
\hline Evre I & $39(28.5-49.5)$ & & & $76.9(56.9-96.8)^{a}$ & & \\
\hline Evre II & $34(20.5-44.2)$ & & & $\begin{array}{l}82.8(58.4-107.2) \\
a\end{array}$ & & \\
\hline Evre IIIA & $23(10.8-35.9)$ & & & $30.0(19.9-43.1)$ & & \\
\hline Adjuvant RT & & 0.06 & 0.801 & & 1.07 & 0.301 \\
\hline Received & $32.0(18.5-45.5)$ & & & $46.0(19.4-72.6)$ & & \\
\hline Did not receive & $360(16.2-55.8)$ & & & $92.0(21.7-162.3)$ & & \\
\hline Adjuvant CT & & 0.01 & 0.433 & & 0.54 & 0.461 \\
\hline Received & $23.0(18.7-46.3)$ & & & $44.0(32.1-55.9)$ & & \\
\hline Did not receive & $32.0(19.9-44.1)$ & & & $57.0(20.2-93.8)$ & & \\
\hline Surgery & & 0.85 & 0.654 & & 0.99 & 0.610 \\
\hline Pneumectomy & $52.0(5.7-114.3)$ & & & $62.8(36.4-89.2)^{\mathrm{a}}$ & & \\
\hline Lobectomy & $32.0(17.7-46.3)$ & & & $57.0(21.2-92.8)$ & & \\
\hline Wedge resection & $50.7(13.3-88.0)^{a}$ & & & $57.0(33.4-80.6)$ & & \\
\hline
\end{tabular}

In those undergoing lobectomy the 2 and 5-year survival rates were $77.1 \%$ and $45.5 \%$,respectively. In those undergoing pneumectomy the rates were $\% 58.6$ and $\% 48.9$, respectively. Finally, in those undergoing segmentectomy the rates were $100 \%$ and $50 \%$, respectively. .

In Table 2, univariate analysis results are outlined for OS and DFS. In multivariate analysis, no independent prognostic factor which was effective on both OS and DSF survival was found.

\section{DISCUSSION}

Lung cancer is very common all over the world and is the leading cause of cancer related deaths. Surgery still remains as the treatment option with a particularly longest survival for NSCLC. The 5-year survival rates are reported to vary between $40-60 \%$ in patients who underwent complete surgery $(3,13$, 14). In the present study, five year survival rate was found to be $45.5 \%$, which is consistent with the literature $(7,14)$. In the study of Pfannschmidt et al. with 2083 patients, the 5-year survival rate was found to be $\% 46.8$ (15). In the present study, 5-year survival rates were over $45 \%$ both in patients who underwent lobectomy and those who underwent pneumenectomy. 
When we evaluate the five year survival rates of locally advanced and metastatic stage, favorable effect of both early stage and surgery on survival is beyond dispute, indicating the importance of early diagnosis and treatment in cases with lung cancer. The relatively fewer number of patients in the present study is a limitation.

Owing to the development of local recurrence and distant metastasis, a long-term prognosis is unfavorable in patients who underwent surgical resection. In the literature, in early-stage patients, the local recurrence rate of $6-11 \%$ and the distant metastasis at the rate of $23-30 \%$ has been reported (4).The remaining viable tumor tisue which can not be detected following the resection is implicated for the development of recurrence. Therefore, within the last two decades, attempts have been made to improve prognosis via postoperative chemotherapy.

In the present study, when all patients were evaluated, no effect of adjuvant CT on survival was shown. However, in a subgroup analysis, in stage IIB cases, significant effect of adjuvant CT on OS was demonstrated. In earlystage cases, it was observed that 5 year DFS rates were higher in those who received adjuvant $\mathrm{CT}$ as compared with those who did not receive it $(41 \%$ vs. $25 \%$ ). However, the difference did not reach the statistical significance. In our opinion this is due to the diversity of chemotherapies administered and to the small number of patients at this stage.

In adjuvant CT studies, various results have been obtained regarding survival. In a meta-analysis performed in 1995 by "Non Small Lung Cancer Collaborative Grup", when patients using alkylating agents and those using cisplatin were evaluated separately, it was observed that treatments containing cisplatin increased survival by $5 \%$ while alkylating agents decreased the survival by $5 \%$ (16). In "Adjuvant Lung Project Italy" (ALPI) study, adjuvant CT was found to be beneficial neither in OS nor in DFS (17). In "International Adjuvant Lung Cancer Trial study (IALT)", favorable effect was found on both parameters. (for OS $p<0.03$ and for DFS $p<0.003$ ) (18). Subsequently, in ANITA, JBR 10 and CALGB 9633 studies, which were carried out with new generation CT agents, the contribution of adjuvant CT to survival was demonstrated (19-21). These studies were evaluated again with the LACE meta-analysis and it was observed that survival benefit was marked in stage II and IIA patients while it was not statistically significant in stage IIB and had a negative impact on survival in stage IA patients (22).

In the present study, when the effect of adjuvant RT on survival was evaluated, it was seen that it had no favorable effect on survival in all early stage cases. In a subgroup evaluation, the positive effect on OS and DFS was seen solely in stage IB and IIB, albeit in a non-statistically significant way. In early stage tumors, the impact of RT on survival is still debatable. Adjuvant RT contributes to locoregional control and is not usually recommended unless surgical margins are positive $(23,24)$. In T1-2, cases without nodal involvement, who underwent complete resection, the benefit of adjuvant RT could not be demonstrated. It is recommended only for patients who can not undergo complete resection and who have residual tumor and high risk (25).

In order to determine patients with low and high risk in early stage NSCLC patients, many studies have been carried out within the last decade $(6,8,26)$. In order to understand tumor biology and to improve treatment outcomes, many investigators tried to determine prognostic factors. However, in these studies, prognostic factors vary due to the heterogenity of the tumor, variation in surgical methods and patient characteristics, weight loss, performance status, the presence of symptoms and advanced stage being well established prognostic factors (27).

In the present study, it was observed that the age over 65 had an adverse effect on both OS and DSF, although this effect did not reach the statistical significance. This finding is consistent with those of Wertezel et al. obtained with 272 patients (28). Likewise, in another study, it was also demonstrated that those at the age of 65 and over had shorter OS and DFS than those of others $(p=0.002)$ (29). Wigren et al. observed that the chance of survival was higher in cases younger than 65 than those over 65 (30). In older-age groups, owing to the treatment complications and comorbid diseases, very few patients had long survival. The importance of age, as a prognostic factor by itself, seems to be small, but comorbid diseases increasing with age are more important determinants.

Conflicting results have been reported regarding the effect of gender. In the present patient series, it was found that female sex had a favorable effect on prognosis, abeit in a non-statistially significant fashion. Overall survival was 53 months in males, while it was 73 months in females. Alexiou et al. also found survival time to be longer in female sex. However, in their study, female patients were younger, male patients had higher rate of comorbid ischemic cardiac disease and their preoperative spirometric measurements were unfavorable which influenced results (31). In addition, in a study involving 20.561 patients, it was found that male sex was associated with unfavorable prognosis (32). Cerfolio et al. reported that female patients had longer survival rates than male patients, but this held true only for stage I and II disease (33). In the present study, female patients were younger and themajority of them were non-smokers and had adenocarcinoma, which may have led to this result.

In younger patients, female sex is a favorable prognostic factor, which is explained by the probable protective function of estrogen and progesteron hormones in tumor growth and by the stimulating effect of androgen hormones on tumor growth. In laboratory studies, it was shown that testesteron increased cellular proliferation but estrogen had no effect on tumor growth (34). In current studies, the relationship between estrogen receptor expression and the prognosis of lung cancer has been demonstrated. While estrogen receptor-alpha expression is associated with adverse prognosis, estrogen receptor beta over expression was reported to be a favorable prognostic factor (35).

Performance status is one of the best clinical indicators in patients with $\operatorname{NSCLC}(27,36)$. In the present study, it was established as a factor influencing both OS and DFS. Patients with satisfactory performance status at the time of diagnosis (ECOG 0 and/or 1) are quite suitable for various treatment modalities. Previously, in patients with curable NSCLC, weight loss, cardiac disease and the presence of COPD were all reported as factors shortening survival considerably (37). In the present study, it was observed that weight loss and comorbidity had no effect on survival.

In the present study, both OS and DFS were found to be better in those with an hemoglobin level over $10 \mathrm{gr} / \mathrm{dl}$. Yovinos et al. demonstrated that preoperative hemoglobin is an independent variable for survival (38). In a large study carried out with 454 patients that underwent surgical treatment, hemoglobin level below $10 \mathrm{gr} / \mathrm{dl}$ was shown to be a prognostic factor (29). Mechanisms such as decreased intestinal iron absorbtion and reduced bone marrow response to erithropoetin are implicated for cancer associated anemia (38). In large majority of early stage cancer patients, the effect of erithropoetin on bone marrow was supressed by cytokines released by tumor. Paul et al. found a correlation between decreased survival and high eritropoetin levels (39).

In the present study, it was determined that, low albumin levels $1<3$ $\mathrm{gr} / \mathrm{dl}$ ), high LDH, leukocytosis and thrombocytosis decreases survival, albeit non-significantly. Mandrekar et al. stated that high leukocyte levels exerted a negative effect on survival in NSCLC patients (40). Ferrigno et al. demonstrated that high leukocyte levels prior to treatment is an independent prognostic factor (41). Higher tumor burden, increase in cytokine release by the tumor (colony stimulating factor, interleukin6 ,vascular endothelial growth factor) or infiltration of the bone marrow by tumor via micrometastasis are among the suggested reasons $(42,43)$. In the study of Shinkai et al., the prognostic importance of albumin and LDH levels was emphasized (42). Conflicting results have been found about the impact of LDH on survival in various studies. However, in a few studies, the LDH level was found to be a prognostic factor $(27,30,40)$. Low albumin level is an indicator of unfavorable nutritional status and was found to be associated with a shorter survival time $(27,40)$. In the present study, no significant relation was found between albumin, $L D H$, leukocyte, thrombocyte levels and survival rates, which may be due to the small number of patients included in the study.

Tumor stage is the most reliable and a well defined determinant of prognosis, as well as, a treatment choice in patients with NSCLC (13). In the present study, TNM stage was found to be influential on both OS and DFS. As stated in many studies, pathological $\mathrm{N}_{2}$ stage was found to be a negative prognostic factor in the present study as well. Ichinosa et al. observed that pathological $\mathrm{N}_{2}$ stage is the most important factor indicating an adverse prognosis in 406 patients that underwent surgery (44). Similarly, Andre et al. showed that preoperatif nodal status is the most important prognostic factor. In their study, they suggested that in these patients mediastinoscopy should be carried out following the evaluation of preoperative N2 by PET in order to improve prognosis (45). $\mathrm{N}_{2}$ disease is a heterogenous group and should be considered as a different biological condition. 
In the present study, a significant inverse relationship was found between adenocarcinoma histology and DFS while no effect of histological type on OS was shown among early stage patients. The previous results regarding the effect of histological type are variable. Harpol et al. demonstrated the prognostic importance of histological type while, Thomas et al. reported that histology had no effect on survival $(46,47)$. In a study, the prognosis of squamos cell carcinoma was found to be better. However, in the study of Ferguson et al, a longer survival time was found in adenocarcinomas $(48,49)$.

\section{CONCLUSION}

In conclusion, the small number of patients is the main limitation of the present study. This may have led to moderate-level risk factors not being detected. Therefore, negative findings should be interpreted cautiously. However, it is our belief that the present study may contribute to the literature in that it is a single-center study which included patients followed up over a long term. In order to determine clinical, pathological and molecular factors influencing survival in operable NSCLC patients, prospective studies with larger series are required.

\section{Conflict of Interest}

No conflict of interest was declared by the authors.

\section{REFERENCES}

1. Jemal A, Siegel R, Ward E, et al. Cancer statistics, 2010. Cancer J Clin 2010; 60:277300.

2. Spiro SG, Porter JC. Lung cancer-Where are we today? Current advances in staging and nonsurgical treatment. Am J Respir Crit Care Med 2002;166:1166-96.

3. Mountain CF. Revisions in the International System for Staging Lung Cancer. Chest 1997; 111:1710-7.

4. Martini N, Burt ME, Bains MS, et al. Survival after resection of stage I and II nonsmall cell lung cancer. Ann Thorac Surg 1992;54: 460-5.

5. Smit EF, Groen HJM, Splinter TAW, et al. New prognostic factors in resectable non small cell lung cancer. Thorax 1996; 51: 638-46.

6. Graziano SL. Non-small cell lung cancer: clinical value of new biological predictors. Lung Cancer 1997; 17:S37-S58.

7. Graziano SL, Tatum AH, Newman NB, et al. S. The prognostic significance of neuroendocrine markers and carcinoembryonic antigen in patients with resected stage I and II non-small cell lung cancer. Cancer Res 1994; 54: 2908-13.

8. Strauss GM. Prognostic markers in resected non-small cell lung cancer. Hematol Oncol Clin North Am 1997; 11: 409-34.

9. Goldstraw P, Crowley J, Chansky K, et al. The IASLC Lung Cancer Staging Project: proposals for the revision of the TNM stage groupings in the forthcoming (seventh) edition of the TNM Classification of malignant tumours. J Thorac Oncol 2007;2: 706-14 10. Groome PA, Bolejack V, Crowley JJ, et al. The IASLC Lung Cancer Staging Project: Validation of the Proposals for Revision of the T, N, and M Descriptors and Consequent Stage Groupings in the Forthcoming (Seventh) Edition of the TNM Classification of Malignant Tumors. J Thorac Oncol 2007; 2: 694

11. Travis WD, Brambilla E, Muller-Hermlink HK, Harris CC (eds). World Health Organization classification of tumours. Pathology and genetics of tumours of the lung, pleura, thymus and heart. IARC Press. Lyon 2004.

12. Oken MM et al. Toxicity and response criteria of the Eastern Coooperative Oncology Group. Am J Clin Oncol 1982;5: 649-55.

13. Van Rens MTM, de la Riviere AB, Elbers HRJ, van den Bosch JMM. Prognostic assessment of 2,361 patients who underwent pulmonaryresection for non-small cell lung cancer, stage I, II, and IIIA. Chest 2000;117:374-9.

14. Al-Kattan, E Sepsas, E R Townsend, S W Fountain Factors affecting long term survival following resection for lung cancer. Thorax 1996; 51: 1266-9.

15. Pfannschmidt J, Muley T, Bulzebruck H, Hoffmann H, Dienemann H.Prognostic assessment after surgical resection for non small cell lung cancer experience in 2083 patients. Lung Cancer 2007; 55:371-7.

16. Non-small Cell Lung Cancer Collaborative Group. Chemotherapy in non-small cell lung cancer: A meta-analysisusing updated data on individual patients from 52 randomized clinical trials. BMJ 1995;311:899-909.

17. Scagliotti GV, Fossati R, Torri V, et al. (ALPi) Randomized study of adjuvant chemotherapy for completely resected stage I, II, or IIIA non-small-cell Lung cancer. J Natl Cancer Inst 2003;95:1453-61.

18. Arriagada R, Dunant A, Pignon JP, et al. Update IALT: Long-term results of the international adjuvant lung cancer trial evaluating adjuvant Cisplatin-based chemotherapy in resected lung cancer. J Clin Oncol. 2010;28:35-42.

19. Douillard JY, Rosell R, De Lena M, et al. Adjuvant vinorelbine plus cisplatin versus observation in patients with completely resected stage IB-IIIA non-small-cell lung cancer (ANITA]): a randomised controlled trial. Lancet Oncol. 2006;7:719-27.
20. Vincent MD, Butts C, Seymour L, et al. Updated survival analysis of JBR.10: A randomized phase III trial of vinorelbine/cisplatin versus observation in completely resected stage IB and II non-small cell lung cancer (NSCLC). J Clin Oncol 2009; 27:382s.

21. Strauss GM, Herndon JE, Maddaus MA, et al. Adjuvant Paclitaxel Plus Carboplatin Compared With Observation in Stage IB Non-Small-Cell Lung Cancer: CALGB 9633. J Clin Oncol. 2008 Nov 1; 26(31): 5043-51.

22. Pignon JP, Tribodet $\mathrm{H}$, Scagliotti GV, et al. Lung Adjuvant Cisplatin Evaluation: A Pooled Analysis by the LACE Collaborative Group. J Clin Oncol. 2008;26: 3552-9.

23. Scott WJ, Howington J, Feigenberg $S$, et al. Treatment of non-small cell lung cancer stage I and II: ACCP evidence-based clinical practice guidelines (2nd edition). Chest 2007;132:234S-242S.

24. Trodella L, Granone $P$, Valente $S$, et al. Adjuvant radiotherapy in non-small cell lung cancer with pathological stage I: definitive results of a phase III randomized trial. Radiother Oncol. 2002;62:11-9.

25. National Comprehensive Cancer Network (NCCN) guidelines. NCCN 2012 (Available at http: // www.nccn.org/professionals/physician/guidelines.accessed on 2012).

26. Kwiatkowski DJ, Harpole Jr DH, Godleski J, et al. Molecular Pathologic Substaging in 244 stage I non-small cell lung cancer patients: Clinical Implications. J Clin Oncol 1998; 16: 2468-77.

27. Paesmans, $M$, Sculier JP, Libert $P$, et al. Prognostic factors for survival in advanced nonsmall cell lung cancer: univariate and multivariate analyses including recursive partitioning and amalgamation algorithms in 1052 patients. J Clin Oncol 1995; 13:1221-

28. Wertzel $H$, Siebert $H$, Lange $W$, et al. Results after surgery in stage-I bronchogenic carcinoma. Thoracic Cardiovasc Surg 1998; 46: 365-9.

29. Jazieh $A R$, Hussain $M$, Howington JA et al. Prognostic factors in patients with surgically resected stages I and II non-small cell lung cancer. Ann Thorac Surg 2000; 70 : 1168-71.

30. Wigren T. Confirmation of a prognostic index for patients with inoperable non-small cell lung cancer. Radiother Oncol 1997; 44: 9-15.

31. Alexiou C, Onyeaka CV, Beggs $D$ et al. Do women live longer following lung resection for carcinoma? Eur J Cardiothorac Surg 2002; 21: 319-25.

32. Radzikowska E, Glaz P, Roszkowski K. Lung cancer in women: age, smoking histology, performance status, stage, initial treatment and survival. Population-based study of 20561 cases Ann Oncol. 2002;13:1087-93.

33. Cerfolio RJ, Bryant AS, Scott E, et al. Women with pathologic stage I, II, and III nonsmall cell lung cancer have better survival than men. Chest 2006; 130:1796.

34. Schwartz AG, Wenzlaff AS, Prysak GM, et al. Reproductive factors, hormone use, estrogen receptor expression and risk of non small cell lung cancer in women. J Clin Oncol 2007; 25: 5785

35. Schwartz AG, Prysak GM, Murphy V, et al. Nuclear estrogen receptor beta in lung cancer: expression and survival differences by sex. Clin Cancer Res 2005; 11:7280-7.

36. Abdul R. Jazieh et al. Prognostic Factors in Patients With Surgically Resected Stages I and II Non-Small Cell Lung Cancer. Ann Thorac Surg 2000; 70:1168-71.

37. Lopez-Encuentra A. Comorbidity in operable lung cancer: A multicenter descriptive study on 2992 patients. Lung Cancer 2002;35: 263-9.

38. Yovino $S$, Kwok $Y$, Krasna $M$, Bangalore $M$, Suntharalingam M. An association between preoperative anemia and decreased survival in early stage non-small-cell lung cancer patients treated with surgery alone. Int J Radiat Oncol Biol Phys 2005; 62: 1438-

39. Paul I, Lappin TR, Maxwell P, Graham AN. Pre-operative plasma erythropoietin concentration and survival following surgery for non-small cell lung cancer. Lung Cancer 2006; 51: 329-34

40. Mandrekar SJ, Schild SE, Hillman SL, et al. A prognostic model for advanced stage nonsmall cell lung cancer. Pooled analysis of North Central Cancer Treatment Group trials. Cancer 2006;107:781-92.

41. Ferrigno D, Buccheri G. Hematologic counts and clinical correlates in 1201 newly diagnosed lung cancer patients. Monaldi Arch Chest Dis. 2003; 59:193-8.

42. Shinkai T, Eguchi K, Sasaki $Y$, et al. A prognostic-factor riskindex in advanced nonsmall-cell lung cancer treated with cisplatin-containing combination chemotherapy. Cancer Chemother Pharmacol 1992;30:1-6.

43. Hoang $T, X u R$, Schiller $J H$, et al. Clinical model to predict survival in chemonaive patients with advanced non-smallcell-lung cancer treated with third-generation chemotherapy regimens based on Eastern Cooperative Oncology Group data. J Clin Oncol. 2005; 23:175-83.

44. Ichinose $\mathrm{Y}$, Kato $\mathrm{H}$, Koike $\mathrm{T}$, et al. Overall survival and local recurrence of 406 completely resected stage IIla-N2 non-small cell lung cancer patients: questionnaire survey of the Japan Clinical Oncology Group to plan for clinical trials. Lung Cancer 2001;34: 29-36.

45.Andre F, Grunenwald D, Pignon JP, et al. Survival of patients with resected N2 nonsmall-cell lung cancer: evidence for a subclassification and implications. J Clin Oncol 2000;18: 2981-9.

46. Harpole DH, Herndone JE, Young WG, et al. Stage I nonsmall cell lung cancer: multivariate analysis of treatment methods and patterns of recurrence. Cancer 1995; 76:787-96.

47. Thomas PA, Piantadosi S. Postoperative T1NO non-small cell lung cancer: squamous versus non-squamous recurrences. J Thorac Cardiovasc Surg 1987; 94:349-54.

48. Alexiou C, Onyeaka CV, Beggs D et al. Do women live longer following lung resection for carcinoma? Eur J Cardiothorac Surg 2002; 21:319-25.

49. Ferguson MK, Wang J, Hoffman PC, Haraf DJ, Olak J, Masters GA, Vokes EE. Sexassociated differences in survival of patients undergoing resection for lung cancer. Ann Thorac Surg 2000; 69:245-50. 